\title{
Cellulitis: Frequent Clinical Entity with Atypical Location
}

Rhizlane Chaoui*, Selma El Kadiri, Samia Mrabet, Zakia Douhi, Sara Elloudi, Hanane Baybay and Fatima Zahra Mernissi

Department of Dermatology, CHU Hassan II, Fez, Morocco

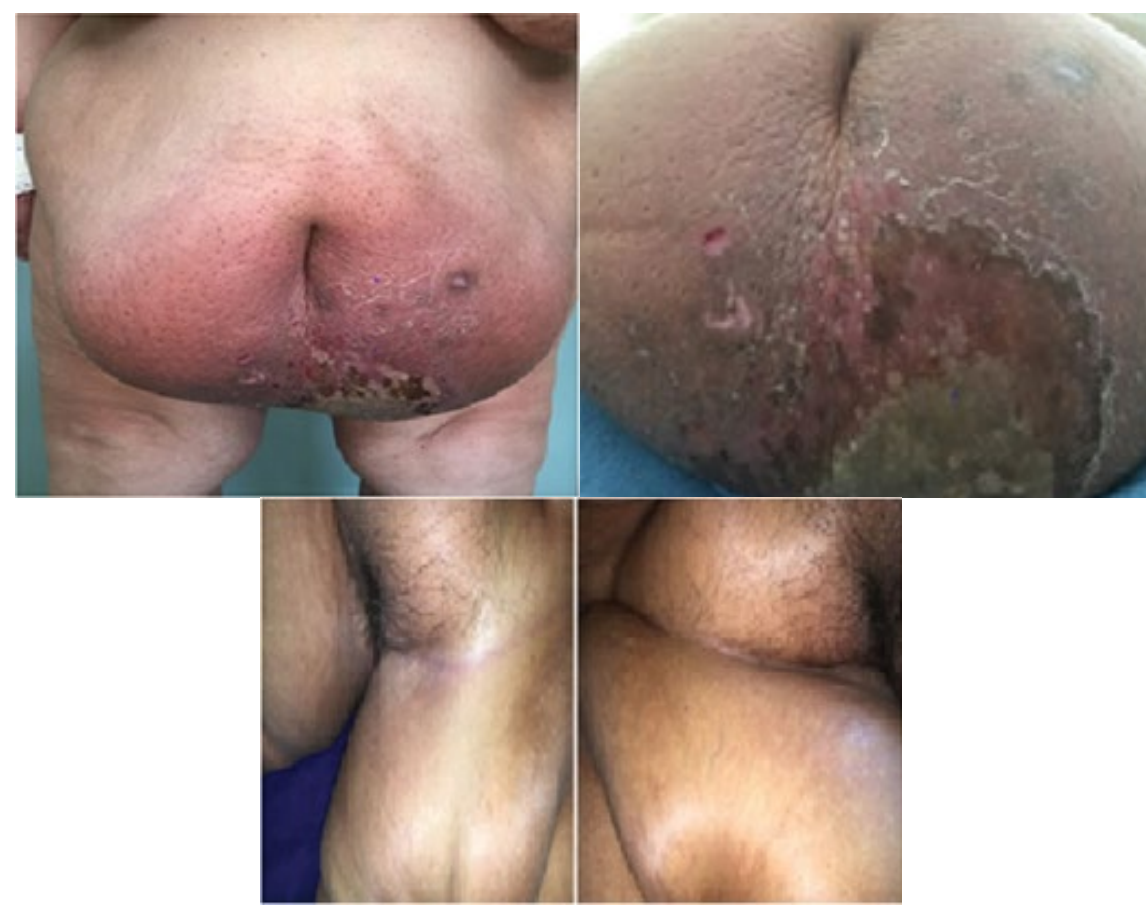

Figure 1: Cellulitis of the abdomen.

Figure 2: Large phlyctene with purulent content in the abdomen.

Figure 3: Bilateral inguinal intertrigo.

\section{Clinical Image}

Cellulitis is an infection of the deep dermis and subcutaneous tissue; the most common causative organisms are Staphylococcus aureus and beta-haemolytic Streptococci. It is presents with expanding erythema, warmth, tenderness, and swelling. Individuals of any age or sex can be affected. It is a quite common infection typically develops in the lower limbs. However, atypical cases may occur about age, underlying morbidity, location or clinical appearance.

A 63-year old female with a hereditary familial obesity; she weighed $160 \mathrm{~kg}$. She was admitted for an erythematous cupboard, hot, painful, and extensive in the abdomen (Figure 1) with purulent blister content (Figure 2), with as an entrance, a bilateral macerated inguinal intertrigo (Figure 3). She has had an encrypted fever and conservation of the general state. The biological assessment showed leukocytosis at $11510 / \mathrm{mm}^{3}$ with C-reactive protein elevated to $97 \mathrm{mg} /$. The treatment consisted of injectable antibiotics based amoxicillin and clavulanic acid dose of $4 \mathrm{~g}$ per $24 \mathrm{~h}$ and Amoxicillin dose of $2 \mathrm{~g} /$ day. The evolution was marked by the progressive regression of cutaneous lesions. The endocrinology consultation for the management of morbid obesity was appropriate.

Keywords: Cellulitis; Infection; Obesity; Tissue

*Corresponding author: Rhizlane Chaoui, Department of Dermatology, CHU Hassan II, Fez Morocco, E-mail: chaoui.rhizlane@gmail.com Citation: Chaoui R, Kadiri SE, Mrabet S, Douhi Z, Elloudi S, et al. (2019) Cellulitis: Frequent Clinical Entity with Atypical Locatio . Int J Clin Med Imaging 6: 629. doi: $10.4172 / 2376-0249.1000629$

Copyright: (C) 2019 Chaoui $R$ et al. This is an open-access article distributed under the terms of the Creative Commons Attribution License, which permits unrestricted use, distribution, and reproduction in any medium, provided the original author and source are credited. 